Meta

Journal des traducteurs

Translators' Journal

\title{
Justice in Jerusalem — Interpreting in Israeli Legal Proceedings
}

\section{Ruth Morris}

Volume 43, numéro 1, mars 1998

La traduction et l'interprétation en Israël

Translation and Interpreting in Israel

URI : https://id.erudit.org/iderudit/003669ar

DOI : https://doi.org/10.7202/003669ar

Aller au sommaire du numéro

Éditeur(s)

Les Presses de l'Université de Montréal

ISSN

0026-0452 (imprimé)

1492-1421 (numérique)

Découvrir la revue

Citer cet article

Morris, R. (1998). Justice in Jerusalem — Interpreting in Israeli Legal Proceedings. Meta, 43(1), 110-118. https://doi.org/10.7202/003669ar

\section{Résumé de l'article}

Cet article évoque l'origine des attitudes qui prévalent aujourd'hui dans le système judiciaire israélien à l'égard de l'interprétation. Il présente les approches qu'ont traditionnellement adoptées les Juifs devant les problèmes de langage dans les tribunaux, ainsi que les solutions pragmatiques adoptées dans les années qui ont suivi la création de l'État d'Israël. Il compare les systèmes d'interprétation fournis en 1961 lors du procès Eichmann, au milieu des années 1980 lors du procès contre Ivan (John) Demjanjuk et dans un certain nombre d'autres affaires impliquant des accusés ne parlant pas l'hébreu. La dernière partie de l'article discute de la qualité de l'interprétation dans les procès "ordinaires" ainsi que dans les "grands" procès publics, dans le système judiciaire israélien.
Ce document est protégé par la loi sur le droit d'auteur. L'utilisation des services d’Érudit (y compris la reproduction) est assujettie à sa politique d'utilisation que vous pouvez consulter en ligne.

https://apropos.erudit.org/fr/usagers/politique-dutilisation/ 


\title{
JUSTICE IN JERUSALEM - INTERPRETING IN ISRAELI LEGAL PROCEEDINGS
}

\author{
RUTH MORRIS \\ Bar-Ilan University, Ramat-Gan, Israel
}

\begin{abstract}
Résumé
Cet article évoque l'origine des attitudes qui prévalent aujourd'hui dans le système judiciaire israélien à l'égard de l'interprétation. Il présente les approches qu'ont traditionnellement adoptées les Juifs devant les problèmes de langage dans les tribunaux, ainsi que les solutions pragmatiques adoptées dans les années qui ont suivi la création de l'État d'Israël. Il compare les systèmes d'interprétation fournis en 1961 lors du procès Eichmann, au milieu des années 1980 lors du procès contre Ivan (John) Demjanjuk et dans un certain nombre d'autres affaires impliquant des accusés ne parlant pas l'hébreu. La dernière partie de l'article discute de la qualité de l'interprétation dans les procès «ordinaires» ainsi que dans les «grands» procès publics, dans le système judiciaire israélien.
\end{abstract}

\begin{abstract}
This article discusses the background to present-day attitudes towards interpreting in the Israeli judicial system. It outlines traditional Jewish approaches to language issues in legal proceedings, as well as pragmatic solutions adopted in the early years of the Jewish state. A comparison is provided of interpreting arrangements at the 1961 trial of Adolf Eichmann, the mid-1980s proceedings against Ivan (John) Demjanjuk, and a number of other cases involving non-Hebrew-speaking defendants. The article concludes with a discussion of quality assurance arrangements in "ordinary" - as opposed to "major" cases in the Israeli justice system.
\end{abstract}

\section{EARLY SIMULTANEOUS INTERPRETATION - THE NUREMBERG TRIBUNALS AND THE EICHMANN TRIAL}

In late 1960, a few months before Adolf Eichmann's trial for war crimes was due to open in Jerusalem in April 1961, a number of individuals began to practise in Israel's parliament to see whether they might be suitable candidates to interpret during the proceedings. Since the accused was a German speaker, as was his defence lawyer, and the proceedings would be conducted in Hebrew - the official language of the State of Israel - interpretation was needed into and from German. In addition, it was known that witnesses would testify in a number of other languages, for which interpretation would also be required. As an event of world interest, the trial had to be comprehensible to media representatives, and so there would also be interpretation into English and French throughout the proceedings.

Simultaneous court interpretation had made its world premiere just over 15 years earlier at the International Military Tribunal in Nuremberg. It was mainly as a result of its relative success there that the fledgling United Nations tried out the technique and eventually adopted it for its proceedings. By 1961, the simultaneous interpreting profession was evolving worldwide. Few of the interpreters in Jerusalem had had experience with court 
work; not all of them had previously acted as simultaneous interpreters. None of them had in the past been required to relay details of atrocities as part of their professional activities.

Acerbic observations about the interpretation at both the Nuremberg trials and the Eichmann proceedings are not lacking. At Nuremberg, England's Judge Norman Birkett referred explosively to "translators" as "a race apart - touchy, vain, unaccountable, full of vagaries, puffed up with self-importance of the most explosive kind, inexpressibly egotistical, and, as a rule, violent opponents of soap and sunlight" (Hyde 1964 : 521 ). Hannah Arendt (1963: 1) described following the Hebrew proceedings in the Eichmann trial "through the simultaneous radio transmission, which is excellent in French, bearable in English, and sheer comedy, frequently incomprehensible, in German".

At Nuremberg, speakers were instructed to limit their rate of delivery to 60 words a minute for the sake of the interpreters: in those early days, it was thought that such a slow rate of delivery would make simultaneous interpreting a feasible exercise (Bowen 1985 : 75). At the Eichmann trial, the two major problems facing the interpreters were the horrific nature of much of the testimony, and the inordinately long sentences and inaccurate expressions characteristic of the German spoken by Eichmann (Hausner 1977 : 355-356). Numerous attempts by the judges, as well as his own defence counsel, to persuade Eichmann to change his style proved futile. Inevitably, the quality of interpretation suffered. Because of the nature of the material, the interpreters at both war crimes trials suffered considerable emotional strain: some found they could not cope and had to be replaced.

\section{LANGUAGES IN THE ISRAELI LEGAL SYSTEM}

The languages spoken at the Eichmann trial represented a small range of those commonly spoken in Israel, a country of immigration par excellence (with a population that has come from over 100 different countries). A book of memoirs by an Israel Supreme Court justice describes court proceedings in Mandatory Palestine and the early days of the State of Israel (Cheshin 1959). Under the British Mandate, the law had recognized three official languages - Hebrew, Arabic and English - in which every citizen was entitled to conduct business with the government. After the founding of the State of Israel in 1948, as in many other areas of life improvisation continued to facilitate the access to justice of those who could not manage in one of these three languages. If a witness could not give testimony in Hebrew, the judge would ask if somebody in the courtroom spoke that person's language. Any degree of self-declared familiarity qualified that individual as an interpreter. Where necessary, a relay system would be improvised, leading eventually to a version of testimony being provided in one of the country's official languages, frequently by a member of the court personnel (Cheshin $1959: 169-172$ ). Cheshin reports that it was not unknown for the members of the public who acted as impromptu interpreters in the courts to be tempted to act as a "teacher and guide" to inexperienced witnesses, as well as to criticize or explain the words of the witness (1959: 23). Such individuals would be thanked politely for their contribution but relieved of their task.

\section{THE RIGHT TO AN INTERPRETER AND INTERPRETING QUALITY}

The linguistic diversity which has characterized life in Israel over such a long period may be one of the factors responsible for the tardy recognition of the need for professional interpreters in the Israeli justice system. On the other hand, the need to provide interpret-

ers for linguistically handicapped participants in legal proceedings in Israel has long been acknowledged. 
In contrast, in the United States, another country of immigration, until the early 1970s the country's leading legal authorities did not even recognise a defendant's right to have the proceedings interpreted. There was also no insistence on quality interpreting services (Chang and Araujo 1975). Despite patchy efforts in the USA over the last quarter of a century to bring about improvements in the area of judiciary interpreting, much still remains to be improved as the country approaches the millennium. In the cradle of the common law, England, it has taken even longer for a tentative recognition of the need for professional interpreting services to evolve among those responsible for the administration of justice (Nuffield Interpreter Project 1993).

\section{SOURCES OF ISRAELI LAW}

As it has developed since Israel's founding in 1948, the system of law practised in the country is based on four systems of jurisprudence, characterized by differing philosophies and linguistic backgrounds. The systems are: British Mandate law, which was in force in Palestine from the end of World War I and, unless otherwise changed, was adopted upon the declaration of Israel's independence; Ottoman law, which had applied during the lengthy Ottoman occupation of Palestine; Jewish religious law, which is mainly relevant to personal status law, such as divorce and succession; and new Israeli law which derives from statute, subsidiary legislation and case law over the last 48 years (Elgrod $1992: 75)$.

The Hebrew language — the language of the Old Testament — was reborn as a modern day-to-day language towards the end of the 19th century and has evolved constantly ever since. Jurists who came to Israel from elsewhere helped develop modern Hebrew legal terminology. Since much Jewish religious law and commentary deals with legal matters, there were solid linguistic and intellectual foundations on which modern developments could build. Aramaic, the language of the Talmud (the primary source of Jewish religious law), plays a role which can be compared loosely with that of Latin in English legal texts.

\section{INFLUENCES ON ATTITUDES TO INTERPRETERS IN THE ISRAELI LEGAL SYSTEM}

In addition to the flexibility and improvisation typical of Israel's development generally, a number of other (sometimes opposing) factors may also influence attitudes to language and interpreters in the Israeli legal system. For example, among the features of the Ottoman legal system that the British left untouched in Palestine was a cavalier approach to written legal translations. Athulathmudall (1962: 228) notes that much of the Ottoman legislation applied in Palestine was a version of French, German or Italian texts, "translated carelessly; simply by a system of word-substitution." To offset the possible drawbacks of this historical state of affairs, when at all possible Israeli judges have examined the original-language (non-Turkish) text in considering Ottoman legislation and its modern ramifications.

Historically, the translation standards applied in English law — another of the major influences on Israeli jurisprudence - have not been renowned for their rigorousness. In earlier days, literal translation led to stylistic monstrosities in English, which, as Mellinkoff points out (1963: 146), "failed to take into account the fact that, unlike inflected Latin, intelligible English depends primarily on word order."

In contrast, the traditional Jewish attitude to mediation of spoken messages through a third party is far more discriminating. For example, a Talmudic text explicitly recognises the difference between active and passive knowledge of a language and the impact that 
using interpreters can have on evaluating evidence: "the Sanhedrin [the tribunal] should not listen (to witnesses) through an interpreter." This somewhat bald statement is elaborated on as follows: "There were these people speaking only a foreign language who came before Rava [the president of the tribunal] in a court proceeding and Rava appointed an interpreter to serve between them. How could he do this? Did we not learn [...] that the Sanhedrin should not hear through an interpreter? Rava was able to understand what they were saying but he was unable to reply" (Babylonian Talmud, Tractate Makkot 6b). In other words, some 16 centuries ago Jewish jurists acknowledged that although the use of an interpreter in order to convey the judge's words to the witnesses is permissible, the judge must be able to understand testimony directly, without the mediation of an interpreter. This approach coincides with the findings of scholars examining the impact of testimony and the importance of presentational style (Loftus 1979; O'Barr 1982). As others have found, the dynamics of legal proceedings are affected in many ways by the intervention of the interpreter as a third party (Berk-Seligson 1990; Morris 1989).

Clearly, however, it is not always practical for the ideal situation - where testimony can be understood in the original language - to prevail. The interpreter may be a necessary evil.

\section{JEWISH SOURCES AND ATTITUDES TO TRANSLATION}

The attitudes found in the Talmud, which contrast markedly with modern English and American lawyers' instructions to interpreters: "translate, don't interpret," relate directly to Judaism's linguistic heritage. As one Hebrew-English translator has pointed out, the Torah (the Pentateuch, or the Five Books of Moses) contains much idiomatic usage, and translating it literally (as do most translations) distorts the meaning of the text (Kaplan 1981 : v-vi). To a large degree, the Oral Torah consists of a tradition as to how to render the idiomatic language of the Torah. Thus, the Oral Tradition teaches that the expression literally translated "between the eyes" (Exodus 13:9) is actually an idiom denoting the centre of the head just above the hairline. To translate it literally would not only go against tradition, but would be incorrect. The Talmud itself warns of this. In one of the most important teachings regarding translation, the Talmud states, "One who translates a verse literally is misrepresenting the text. But one who adds anything of his own is a blasphemer" (Talmud: Kiddushin 49a; Tosefta, Megillah 3:21). Maimonides, the great mediaeval Jewish jurist, provided the translator with wise advice along the same lines (letter to Shmuel ibn Tibbon, 1199). The modern court interpreter is often in a similar quandary.

\section{THE 1961 EICHMANN TRIAL}

In contrast to the Ottoman and English approaches to translation activities, it was the punctilious Jewish approach which governed the attitude of the bench at the 1961 Eichmann trial to the provision of interpreting services and the record of these multilingual proceedings.

The practice in the overwhelming majority of countries and cases involving interpreters is for the official court record to be produced exclusively in the language of the court. It is extremely rare for any record to be kept of what is said in the "other" language. When the written court record is of major importance - for example, in the Israeli nonjury system it is reviewed by the bench in reaching its verdict — interpreter errors may prove decisive. 
Aware of this state of affairs, the Eichmann bench reached a compromise. The "ideal" situation — to conduct the trial entirely without interpretation — was unacceptable. Since Hebrew is Israel's primary official language, and the accused was a Germanspeaker, although the bench had no need of interpretation it would have been inappropriate to dispense with interpreters. It was necessary to ensure that everything said at the trial could be understood by the Israeli public, as well as the local and foreign media.

The compromise adopted was to try to ensure that the highest possible quality was achieved by the interpreters. Thus the judges - all born and mainly educated in Germany - constantly monitored and corrected the consecutive Hebrew interpretation, which formed the record of the proceedings. Despite their care, they pragmatically acknowledged that mistakes would inevitably be present in the Hebrew interpretation of Eichmann's evidence, and agreed to treat the original German words as the authoritative version when reviewing the record in order to reach their verdict. The Talmudic approach was thus fully applied.

Every day, a complete transcript of the proceedings was produced and distributed in four languages (Hebrew, English, French and German), each bearing a cautionary note to the effect that the text contained an unrevised simultaneous interpretation. A complete videotape recording of the trial was also made, as well as an audio recording. In addition, a Hebrew shorthand record was made.

Although the proceedings were officially conducted in Hebrew, with typically Israeli flexibility, the judges questioned the accused in German. The examination by the police had similarly been conducted in German. For the prosecution, Attorney-General Gideon Hausner asked his questions in Hebrew; but at a particularly vital stage in his cross-examination, the slowness of consecutive interpretation so exasperated him that he switched to questioning Eichmann in German (Hausner 1977 : 364). The pragmatic willingness of the bench and prosecution to use German is remarkable given the fact that at the time, because of the Holocaust, a large proportion of the Israeli population still had a negative attitude to all things German, including the language.

Over 30 years later, an authoritative English version of the entire trial was published, completely retranslated from the original languages and edited by the judge who presided over the 1961 proceedings. The choice of English acknowledges the pivotal international role of that language in the late 20th century, and the need to make this material available to as wide an audience as possible.

\section{WORLD MEDIA INTEREST IN ISRAELI LEGAL PROCEEDINGS}

In the last four decades, the interest of the world media has from time to time focused on certain legal proceedings taking place in Israel, including the 1961 Eichmann trial (Hebrew consecutive, and German, English and French simultaneous versions being provided throughout the trial); the 1969 trial of the Australian tourist (Rohan) who set fire to the Al Aqsa mosque in Jerusalem (with English, Hebrew and Arabic simultaneous interpretation in court, following remand proceedings conducted entirely in English); the 1972 trial of two Arab women (Tannous and Halasseh) who hijacked a Sabena plane to Israel's Lod Airport (an Arabic-Hebrew interpreter providing consecutive and whispered interpretation in court); the 1972 case against Japanese terrorist Okamoto, who was involved in the May 1972 massacre at Lod Airport (the trial requiring consecutive Hebrew, and simultaneous Japanese and English interpretation); and the 1987 proceedings against suspected war criminal Ivan Demjanjuk (with Hebrew (consecutive), English (simultaneous), and Ukrainian (whispered) interpretation throughout the trial, plus German and Yiddish for some testimony). 
The standard of interpreting for the various languages at these different proceedings has varied widely. The calibre of the professional Hebrew-English interpreters at the Okamoto trial contrasted markedly with the valiant but below-standard efforts of the two court-appointed Japanese-Hebrew interpreters. One was a Japanese Bible student who was engaged for the trial despite his weak spoken Hebrew and lack of experience as an interpreter. At the Demjanjuk trial, the three interpreters who took turns to provide a whispered Ukrainian version of the proceedings did not all achieve an acceptably high level. When the accused requested that one of these individuals not be allowed to work during his own examination, he was reprimanded by the presiding judge. The consecutive Ukrainian-toHebrew interpretation was monitored by an additional interpreter engaged by the prosecution, who identified as problematic certain renderings by the official court interpreter.

The use of the consecutive technique, provided by inexperienced interpreters, for the provision of a Hebrew version of the accused's testimony became a matter of complaint at both the Okamoto and the Demjanjuk trials. In both cases, a need was found to interrupt the speaker after a few words only in order to enable the interpreters (working from Japanese and Ukrainian respectively) to achieve accuracy, as they had no experience in notetaking. Objections to these interruptions were put forward by Demjanjuk's defence lawyer, and by Okamoto himself, who suddenly shouted in English, "I have not completed, I want to talk" (Jerusalem Post, July 14, 1972).

\section{QUALITY ASSURANCE - EICHMANN VS DEMJANJUK}

Generally speaking, in contrast to the situation at the 1961 Eichmann proceedings, monitoring of the interpretation at the Demjanjuk trial was neither consistently performed nor an objective linguistic matter, despite the fact that all of the Demjanjuk proceedings were broadcast live on both radio and television. The reasons probably lie in the linguistic skills of the two panels of judges, as well as in differences in their attitudes towards and acceptance of responsibility for interpretation quality. It may also be that the increase in the proportion of native Hebrew speakers in Israel's population that occurred between 1961 and 1986 affected attitudes towards speakers of other languages.

To some extent, the linguistic handicaps of the three-judge Demjanjuk panel can be compared with those of the bench at the International Military Tribunal at Nuremberg. There, at least one of the accused, Hermann Göring, was able to exploit this state of affairs in arguing that he had been misinterpreted on a number of occasions (Bowen 1985: 76). In this respect, the Demjanjuk proceedings contrast markedly with the quality-assurance measures at the Eichmann trial held a quarter of a century earlier (Morris 1989).

\section{THE INTERNATIONAL DIMENSION - TESTIMONY AND RECORDS}

At times, proceedings held elsewhere may have an Israeli dimension, for example by involving witnesses or interpreters who live in Israel. For example, a link between the Demjanjuk trial in Israel and earlier proceedings held in Fort Lauderdale, Florida, against a former concentration camp guard (Fyodor Fedorenko) is provided by the Treblinka camp. All the eyewitnesses (including those from Israel) who testified in both cases had been incarcerated in Treblinka, and Fedorenko had been a guard there.

At the Demjanjuk trial in Jerusalem, when cross-examining a witness who had previously testified in the United States, the American defence lawyer quoted from the witness's evidence as it appeared in the English-language record of the Fort Lauderdale proceedings. In Florida, the witness in question had testified in Hebrew, and his evidence had been interpreted into English by a court interpreter who was federally certified - but 
only for the Spanish-English combination. As is standard practice, no written record was made of the original testimony.

It is a moot point whether the error in question occurred on the level of the HebrewEnglish interpretation (which all those present at the trial who had the linguistic skill to judge agreed was not satisfactory) or of transcription. The witness had referred to "Jaffa" (in Hebrew, pronounced Yafo), but the record showed "Haifa" (in Hebrew, Heyfa or Hayfa). These two Israeli localities are approximately 100 kilometers apart.

In Jerusalem, the bench rejected out of hand the American lawyer's attempt to discredit the witness by challenging the discrepancy between his earlier testimony and what he said in his evidence in the Demjanjuk proceedings. In an American jury trial, such a tactic might have had a greater chance of succeeding. This tiny incident illustrates the potential snowball effect which can occur unless stringent quality assurance standards are applied in court interpreting practices everywhere.

\section{THE INTERNATIONAL DIMENSION — INTERPRETERS FROM ISRAEL}

In addition to Israeli witnesses who testify in cases abroad, a further international link is provided by interpreters from Israel. An example of this is Australia's first prosecution for WWII war crimes (Polyukhovich). Many of the eyewitnesses were Hebrew- or Ukrainian speaking. Two Australian-based Hebrew interpreters were used during the committal hearing. The first was replaced after proving plainly inadequate on the first day and the second was also considered inadequate and was openly criticised for inaccuracy and shouted at in court by one witness for whom he was interpreting. Another witness refused to sign the transcript of his evidence on the grounds that it had been mistranslated. The Ukrainian interpreting also seemed to cause some problems and after the committal, it was found by an independent expert that the Ukrainian witnesses had been disadvantaged by the Australian judicial system, not only because of inadequate interpreting but also due to cultural differences and misunderstanding (personal communication).

Prior to the actual trial, the judge went through the transcript of the committal hearing and reportedly said that "he marvelled how so much had been spent in preparing and presenting the case and yet, at the practical stage of taking evidence, the interpreting was obviously deficient" (Bevan 1994). Conclusions were drawn from the problems with interpreting at the committal hearing, and qualified professional interpreters, some of them recruited from outside Australia (including Israel), were engaged for the Supreme Court hearing.

\section{INTERPRETING ARRANGEMENTS FOR MAJOR VS ORDINARY CASES}

As described above, on the whole commendable efforts are made to provide satisfactory interpretation for major cases in Israel in which non-Hebrew speakers are involved, as described above. The situation is somewhat more gloomy, however, for ordinary proceedings. This situation is far from being unique to Israel: as has been pointed out for Britain by a member of the House of Lords, "interpretation services are provided in the serious cases. It is at the lower end of the ladder that frequently they are not provided" (Lord Richard, House of Lords, March 26, 1991).

Although Israel explicitly recognizes the court's duty to provide interpretation for an individual who "does not know" Hebrew (1965 Criminal Procedure Law, Paragraph 128), it has set no quality assurance standards and issued no regulations about recruitment arrangements. In line with Israel's linguistically flexible tradition, judges are legally allowed to act as linguistic intermediaries ("the court shall appoint a translator or itself act 
as translator" - 1965 Criminal Procedure Law, Paragraph 128). Thus sometimes a judge will provide a Hebrew-language version as he dictates the record to the typist who enters the proceedings in the computer.

Following large-scale immigration from the former Soviet Union around 1990, the large numbers of cases involving Russian speakers are now coming before Israel's courts, with interpreters being engaged on a fairly haphazard basis with inadequate quality controls. Anecdotal evidence indicates that witnesses with a smattering of Hebrew are encouraged to testify without an interpreter, being assisted by a helpful and encouraging judge. Sometimes such helpfulness can lead to inadvertent misrepresentation of testimony.

Frequently court interpreters are recruited from among university students, who often have no experience in the area, no knowledge of legal and other matters, and whose linguistic and interpreting skills are untested. Arrangements for interpreters to appear in court may also be unreliable. In at least one documented instance, administrative inefficiency led to an offence not being tried because an interpreter failed to turn up for three separate hearings of the same case.

None of these shortcomings are exclusive to court interpreting in Israel. Indeed, the country may be considered to be more likely than many others to offer equity of access because of the persisting tradition of multilingualism among its judiciary and lawyers. The contrast between the system's willingness to recruit professional interpreters and use simultaneous interpretation for trials which are considered major on a world level and the use of unprofessional individuals for ordinary cases is a standard occurrence. Rates of pay for court work vary accordingly, ranging from around $\$ 10$ an hour with no minimum to $\$ 200$ or more a day. Quality control, for which an accurate record of the proceedings is vital, varies equally widely: practice varies from no electronic record or transcript of nonHebrew material on the one hand, to a full electronic recording of everything said in court (with the exception of whispered interpretation) and written transcripts of practically all original and interpreted material.

Although the need for professional interpreters in the Israeli court system is recognized by lawyers and judges alike, no official steps have been taken to recruit and organize a body of experienced court interpreters for the major languages used in the legal system. Some courts employ one or more Hebrew-Arabic staff interpreters. Generally, however, those who interpret in routine procedures in Israel's courts are recruited on an ad hoc basis and perform with varying levels of skill. A few years ago, the new president of Jerusalem's District Court mentioned court interpreting, particularly from Arabic, as one of the areas requiring reform (Halishka, 9, 1990 : 8-9). His investigations of the situation soon ran into the standard litany of excuses and blank walls, and, in defeat, he abandoned his efforts to improve the situation (personal communication).

\section{PLUS ÇA CHANGE...}

The predicament of the well-intentioned Israeli judge of the early 1990s would come as no surprise to his counterparts in other countries and in earlier times. Brave words and agonized identification of linguistically derived injustice are not absent from the legal literature. For example, in the 1889 Michigan case of Rajnowski (Rajnowski v. Detroit, B.C. \& A.R. Co., 41 N.W. 849 (1889)), the Supreme Court of Michigan made the following apt remarks:

In numerous contested cases, testimony has been taken by means of interpreters. In very many instances the conflict of testimony is such as to indicate either more perjury than seems possible, or more likely incorrect renderings of testimony [...] 
It is necessary to employ the help of those who are supposed to understand both languages, and to be capable of transmitting correctly from each to the other all that is said by either person dealing with another. But the danger of mistakes in legal proceedings is such that nothing but practical necessity can justify the intervention of an interpreter between counsel and witness or witness and jury, although it is well settled that on a proper occasion it is allowable, and the occasion must usually be judged of by the trial court [...]

It is necessary, for the due course of examination, that the interpreter shall give to the witness the precise form and tenor of each question propounded, and no more or less, and that he shall in like manner translate the precise expressions of the witness [...]

It often happens that the chance interpreter who is picked up is ignorant, or otherwise not the right person, and that he takes liberties with both questions and answers. All who have had experience in trials have found serious evils inevitable under our present system of chance and temporary appointments, and have found themselves powerless to prevent mischief, intended or unintended.

If stenographers could take down what is said by interpreters and witnesses in other languages, it might furnish some help, by giving means of resorting to other translators to test their accuracy; but this is also impracticable, and the stenographer's minutes contain the questions in English, and the interpreter's English rendering of the answers, with no means of judging the correct report of either, as between interpreter and witness [...]

We have seen so many instances in the records before us of testimony which appeared of questionable accuracy that, while it is beyond our power to correct the evil, we deem it proper to advert to the occasion for having it corrected, if possible. It is not for us to do more than call attention to it.

In the intervening century since the above was written, much has changed in Michigan, and even more has changed in the Middle East. Yet the introduction of modern electronic and communications wonders such as tape-recording and computerization has done little, if anything, to change the legal system's behaviour in addressing the range of issues identified above. Well-meaning judges continue to call attention to "the serious evils" that still exist in the interpreting practices that prevail in the vast majority of legal systems in the world, yet little gets done. With a few notable exceptions, Israel's record is no better and no worse - than that of most common-law systems. In this area, the country would appear to have absorbed the laissez-faire attitude of the former colonial powers, and not yet acted upon the more punctilious and enlightened Jewish traditions in respect of translation generally and court interpreting in particular.

\section{REFERENCES}

ATHULATHMUDALL, L. W. (1962) : "The Language of the Courts", Malaya Law Review, 4 (2), pp. $221-232$. BERK-SELIGSON, Susan (1990) : The Bilingual Courtroom: Court Interpreters in the Judicial Process, Chicago, University of Chicago Press.

BEVAN, David (1994) : A Case to Answer: The Story of Australia's First European War Crimes Prosecution, Australia, Wakefield Press.

BOWEN, David and Margareta BOWEN (1985): "The Nuremberg Trials (Communication through Translation)", Meta, 30 (1), pp. 74-83.

CHANG, Williamson B. C. and Manuel U. ARAUJO (1975) : "Interpreters for the Defense: Due Process for the Non-English-Speaking Defendant", California Law Review, 63 (3), pp. 801-823.

CHESHIN, Shneour Zalman (1959) : Tears and Laughter in an Israel Courtroom, translated from the Hebrew by Channah Kleinermann, Philadelphia, Jewish Publication Society of America.

ELGROD, Stuart (1992): "Legal Translators in Israel", Joanna Miler (Ed.), International Forum of Legal Translation 1992, Proceedings, TEPIS Ltd., Warsaw, pp. 75-80.

Government of Palestine (c.1920) : Rule of Court: Language of Pleading.

Government of Palestine (c.1920) : Use of Official Languages.

HAUSNER, Gideon (1977) : Justice in Jerusalem, Jerusalem, Herzl Press.

HYDE, H. Montgomery (1964) : Norman Birkett, London, Hamish Hamilton. 
KAPLAN, Aryeh (1981): Translator's Introduction to The Living Torah, New York and Jerusalem, Maznaim Publishing Corporation.

LOFTUS, E. F. (1979) : Eyewitness Testimony, Cambridge (Mass.), Harvard University Press.

MAIMONIDES, (Moses ben Maimon), Letter to Shmuel ibn Tibbon in 1199, translated (1) by Leo W. Schwarz, Memoirs of My People (1943) at x, quoted in Rosenne, Shabtai (1971) : "On Multilingual Interpretation", Israel Law Review, 6, pp. 360-366 at p. 361, and (2) by Kaplan, Aryeh.

MELLINKOFF, David (1963) : The Language of the Law, Boston \& Toronto, Little, Brown \& Company.

MORRIS, Ruth (1989) : "Court Interpretation and the Record of Legal Proceedings: Eichmann v. Demjanjuk", Parallèles, Cahiers de l'École de traduction et d'interprétation, Université de Genève, n 11, pp. 9-28.

MORRIS, Ruth (1989): The Impact of Court Interpretation on Legal Proceedings, M.A. Thesis, Communications Institute, Hebrew University of Jerusalem.

Nuffield Interpreter Project (1993): Access to Justice: Non-English Speakers in the Legal System, London, Nuffield Foundation.

O'BARR, William M. (1982) : Linguistic Evidence: Language, Power, and Strategy in the Courtroom, New York, London, Paris, Academic Press. 